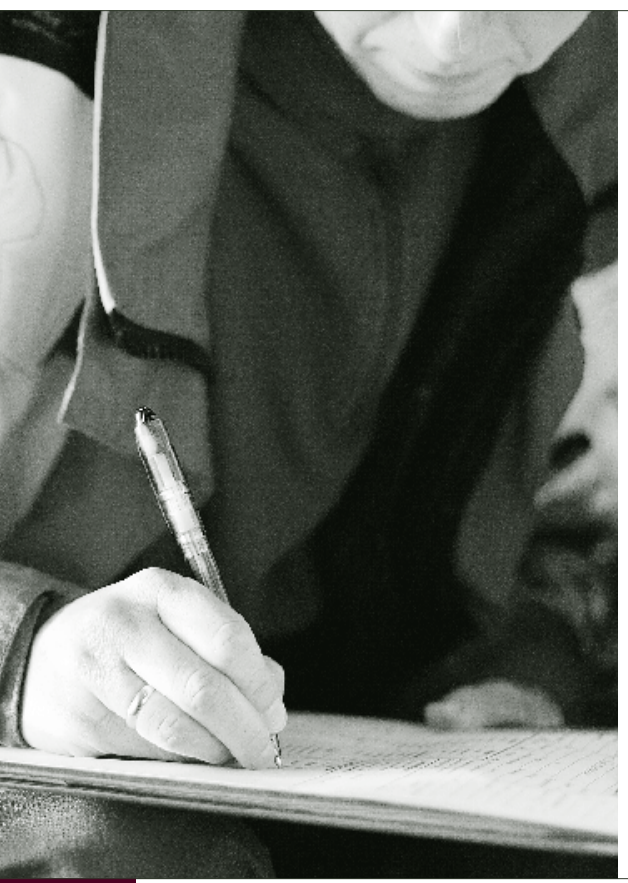

Bakgrunn: Heroinoverdoser behandles oftest av ambulansetjenesten, men vi vet lite om denne behandlingen gir rom for å sikre forsvarlig helsehjelp og oppfølging.

Hensikt: Hensikten med denne studien var a) å belyse tidsbruken ved prehospital overdosebehandling og om overdosepasienter blir ferdigbehandlet på stedet eller får videre medisinsk oppfølging, samt b) å unders øke hvorvidt kliniske kjennetegn ved pasienten har betydning for tidsbruken og ferdigbehandling på stedet.

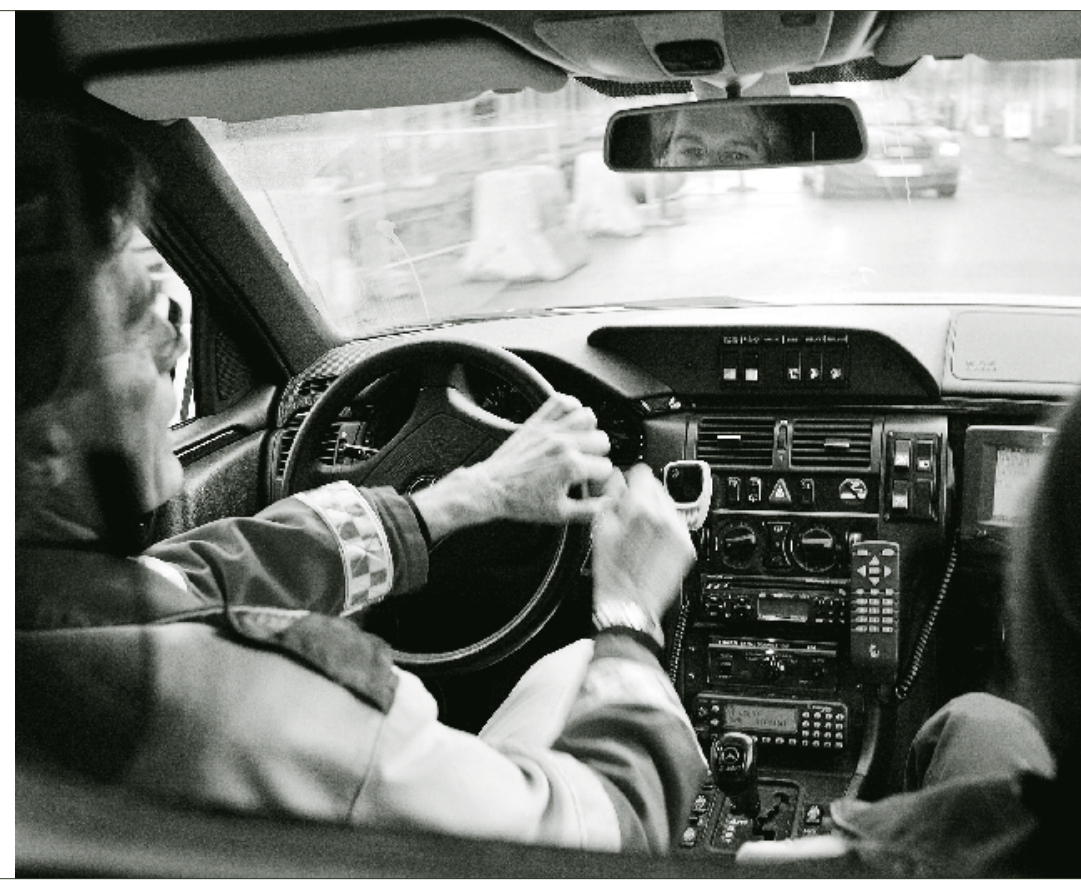

Metode: Data fra ambulansejournaler ved prehospital naloxonebehandling av ikke-fatale heroinoverdoser i Oslo i årene 1998, 1999 og 2000 ble analysert ( $n=2700)$.

Resultater: Ambulansetjenesten brukte i gjennomsnitt 16,8 minutter totalt på hver pasient. Blant eldre pasienter (> 40 år) og pasienter med respirasjonssvikt og nedsatt bevissthet var tidsbruken noe lengre enn hos andre pasienter. I alt 82,3 prosent av pasientene ble ferdigbehandlet på stedet. Denne andelen var noe lavere dersom tidsbruken oversteg 20 minutter.

Konklusjon: Til tross for en potensiell fysisk og psykisk svekkelse, ble en stor andel av pasientene som hadde vært i en akutt livstruende situasjon, kun observert i kort tid, og de fleste mottok ikke påfølgende behandling i en medisinsk klinikk. Vi foreslår videre studier av pasientene som mottar naloxonebehandling og behandlingsstrategien.
Time used for overdose treatment in Oslo

Background: Most heroin overdoses are treated by the ambulance service, but we know little about whether proper health care and follow-up can be ensured by this treatment.

Objective: The purpose of this study was a) - to assess the amount of time spent on pre-hospital treatment and whether this treatment is terminated on-site or followed by further medical attention, and b] to investigate the importance of the clinical characteristics of the patient for these conditions.

Method: Data from ambulance rekords of pre-hospital naloxone treatment of non-fatal heroin overdoses in Oslo in the years 1998, 1999 and 2000 were analyzed $(n=2700)$.

Results: The ambulance team spent an average of 16.8 minutes total on each patient. Among older patients (> 40 years) and patients with respiratory failure and impaired consciousness the ambulance team spent somewhat more time, compared to other patients. In most cases, $82,3 \%$, the treatment was termi- nated on-site. This percentage was somewhat lower if the time spent exceeded 20 minutes.

Conclusion: Despite a potential physical and mental deterioration, a large proportion of patients who have been in an acute life-threatening situation were only observed in a very short period, and most of them did not receive subsequent treatment in a medical clinic. We suggest further studies of patients receiving naloxone treatment and the strategy of this treatment.

Keyword: Heroin, overdose, naloxone, prehospital treatment 


\section{» Tidsbruk ved behandling av overdoser i Oslo}

Forfattere: Ståle Alstadius og

Ingeborg Rossow

\section{NøKKELORD}

- Stoffmisbruk

- Overlevelse

- Akuttsykepleie

\section{INNLEDNING}

Mange som injiserer heroin har opplevd en eller flere overdoser (1), og nesten alle heroinoverdoser skjer ved injisering og ofte når heroinbruk kombineres med bruk av alkohol eller medikamenter som benzodiazepiner (2). Ved en livstruende overdose har pasienten lavt blodtrykk og svekket blodomløp, bevissthetstap og respirasjonssvikt/-stans. Oksygenmangelen som følge av respirasjonssvikten kan føre til hjerneskade (3), skade på hjerte og muskulatur, og svekket kognisjon (4). Umiddelbart etter respirasjonsstans eller respirasjonssvikt må pasientens kognisjon antas å være betydelig nedsatt (5). Hjerneskader kan svekke pasientens funksjonsevne i alvorlig grad og kan være undervurdert som konsekvens av overdoser (6). Dette tilsier at pasienter behandlet for livstruende overdoser kan ha betydelige problemer med å forstå rekkevidden av hendelsen, og det vil derfor være viktig at de umiddelbart får adekvat oppfølging.

Psykiske lidelser som angst og depresjon er svært utbredt blant narkotikabrukere (7-9), og en betydelig andel har forsøkt å ta sitt eget liv en eller flere ganger (10-14). Pasientgruppen har derfor også et vesentlig behandlingsbehov utover akutt behandling av overdose. Overdosepasienter har en høy risiko for påfølgende overdoser i løpet av uker/måneder (1,15-17). Vurdering av pasientenes risiko for å ta nye overdoser kan være viktig $i$ et forebyggingsperspektiv.

Så vel i Norge som i andre land, blir heroinoverdoser i første omgang vanligvis behandlet prehospitalt av ambulansetjenesten på stedet der pasienten blir funnet. Ofte benyttes opiatantagonisten naloxone for å reversere heroineffekten (18). De fleste pasientene vil da komme til bevissthet og oppnå tilfredsstillende respirasjon. Men i hvilken grad pasientene følges opp med videre medisinsk behandling i akuttmottak eller sykehus, varierer betydelig (18). Eksempelvis har studier fra California og Østerrike vist at omkring 10-30 prosent av overdosepasientene ble ferdigbehandlet på stedet, mens de øvrige ble overført til videre medisinsk behandling (19-21). På den annen side har studier fra Melbourne, Australia (22), København (23) og Oslo (24) funnet at det store flertallet av overdosepasientene (omkring 85 prosent) ble ferdigbehandlet på stedet, og altså ikke fulgt opp videre $\mathrm{i}$ det medisinske behandlingsapparatet. Mellom

\section{Hva tilfører artikkelen?}

Funnene i studien kan tyde på at ambulansepersonellet i mange tilfeller ikke har hatt tilstrekkelig observasjonstid til å forsvarlig vurdere om det er nødvendig med videre medisinsk oppfølging av pasienten.

\section{Mer om forfatterne:}

Ståle Alstadius er spesialsykepleier og forsker ved Seksjon rus- og avhengighetsbehandling ung, Klinikk psykisk helse og avhengighet, Oslo universitetssykehus. Ingeborg Rossow er forsker ved Statens institutt for rusmiddelforskning (Sirus). Kontakt: roozt1ayahoo.no. 
disse ytterpunktene ligger funn fra studier i Helsinki (25) og i Hellas (26) hvor denne andelen lå på omkring 50 prosent. Dietze og medarbeidere fant at selv mellom australske delstater varierte denne andelen mellom 6 prosent og 81 prosent (27). En sammenlikning av studier av naloxonebehandlede overdoser i Oslo viser at andelen som ble ferdigbehandlet på stedet var klart lavere i 2003/2004 (73 prosent) (18) enn hva den var fem år tidligere i 1998/1999 (85 prosent) (24). observasjonstiden etter gjenvunnet tilfredsstillende respirasjon og bevissthet, er av betydning for å avdekke eventuelle overdoserelaterte komplikasjoner og andre behandlingskrevende forhold, samt ha betydning for kommunikasjon, psykososial ivaretakelse og trygghet for pasienten. Anbefalt observasjonstid på medisinsk grunnlag varierer i forskningslitteraturen, men med et minimum på én time (29). I de fleste tilfeller er ambulansetjenesten, som primært har en akuttmedisinsk

\section{Det store flertallet av overdosetilfellene ble ferdigbehandlet på stedet.}

Hvilke forhold som kan forklare de store forskjellene i behandlingspraksis mellom land eller over tid synes i liten grad å ha blitt undersøkt. Det synes heller ikke å være utført systematiske undersøkelser av hvilke forhold som er av betydning for den individuelle variasjonen. Noe av forskjellene som er avdekket mellom land kan trolig begrunnes med ulike inklusjonskriterier i studiene, politiets involvering og ambulansetjenestens organisering (28). En norsk studie foreslo at den høye andelen pasienter som ble ferdigbehandlet på stedet kunne forklares med en liberal tradisjon blant ambulansepersonellet i Oslo om å akseptere pasientens ønske om ikke å bli hospitalisert eller å betrakte en videre medisinsk oppfølging som unødvendig (18).

Vi vil anta at ambulansepersonalets vurdering av behov for videre medisinsk oppfølging i første rekke er betinget av pasientens somatiske og psykiske tilstand. Vi vil også anta at funksjon og begrensende muligheter til å følge anbefalt observasjonstid på stedet, den eneste helsehjelpen pasienten mottar i forbindelse med overdosen. Som et grunnlag for å vurdere i hvilken grad ambulansetjenestens observasjonstid er tilstrekkelig og forsvarlig helsehjelp, både $\mathrm{i}$ forhold til hva som er anbefalt på medisinsk grunnlag og i forhold til kliniske kjennetegn ved behandlingsstart, vil måling av tidsbruk være nyttig. Vi har ikke funnet studier hvor tidsbruken har blitt målt når behandlingen avsluttes prehospitalt.

Hensikten med denne studien var derfor å belyse tidsbruken ved prehospital overdosebehandling og om overdosepasienter blir ferdigbehandlet på stedet eller får videre medisinsk oppfølging, og hvorvidt kliniske kjennetegn ved pasienten har betydning for disse forholdene.

\section{DATA OG METODER}

Studien bygger på retrospektivt innhentete data fra ambulansejournalene ved alle ambu- lanseutrykninger til overdoser i Oslo i årene 1998, 1999 og 2000. Ambulansepersonalet fylte ut et skjema som blant annet omfattet følgende opplysninger: Dato, tidspunkt for tilkalling av ambulanse, klokkeslett for ankomst, pasientens kliniske status ved ankomst (respirasjon og bevissthet), behandling med naloxone, tidspunkt for avsluttet behandling på stedet og videre oppfølging av pasienten. Statens institutt for rusmiddelforskning har fått tilgang til dataene fra Oslo legevakt, og det er gitt samtykke til dispensasjon fra taushetsplikten fra Statens helsetilsyn. Bruk av dataene $\mathrm{i}$ anonymisert form er godkjent av Regional komité for medisinsk forskningsetikk og Datatilsynet, og data er tidligere brukt i en studie om alkoholens betydning for ikke-fatale overdoser hvor opiater er inntatt (30).

\section{Utvalg}

I løpet av årene 1998, 1999 og 2000 registrerte ambulansetjenesten i Oslo i alt 5641 utrykninger i forbindelse med overdose. Av disse var det 4520 utrykninger hvor opplysninger om pasientens kliniske status ved ankomst og/eller behandling med naloxone indikerte at det dreide seg om en overdose av et opioid. Informasjon om kjønn og alder var basert på personnummer, og blant opioidoverdosene var det 3838 utrykninger hvor journalen hadde personnummer (30). Av disse opioidoverdosene med informasjon om kjønn og alder var det i alt 2700 som ble behandlet med naloxone. Vi antar at dette underutvalget representerer de mer livstruende tilfellene av overdoser. Dette understøttes av opplysningene om pasientens 
TABELL 1: Pasienter med behandlingstid mer enn 10 minutter etter kjønn, aldersgruppe, respirasjon og bevissthet ved ankomst.

\section{Teststatistikk}

n (\%) Kjikvadrat (p-verdier) Odds ratio (95\% KI)

\begin{tabular}{|c|c|c|c|}
\hline Alder & & & \\
\hline$\leq 25$ & 237 (75) & $\begin{array}{c}8,42 \\
1,015)\end{array}$ & 1 \\
\hline $26-39$ & $957(76)$ & & $1,1(0,8-1,4)$ \\
\hline $40+$ & 325 (83) & & $1,6(1,1-2,3)$ \\
\hline
\end{tabular}

Respirasjon

$\begin{array}{lccc}\text { Normal } & 241(71) & \begin{array}{c}12,18 \\ (0,002)\end{array} & 1 \\ \text { Insuffisient } & 942(78) & & 1,4(1,1-1,9) \\ & & \\ \text { Stans } & 288(82) & 1,8(1,3-2,6)\end{array}$

Bevissthet

\begin{tabular}{lccc} 
Våken & $76(67)$ & $\begin{array}{c}15,60 \\
(0,000)\end{array}$ & 1 \\
Somnolent & $215(72)$ & & $1,2(0,8-2,0)$ \\
Komatøs & $1219(79)$ & $1,8(1,2-2,8)$ \\
\hline
\end{tabular}

kliniske tilstand før behandlingsstart. For 749 av disse 2700 overdosene var skjemaet mangelfullt utfylt for en eller flere variabler, slik at det var i alt 1951 opioidoverdoser som ble behandlet med naloxone og hvor det var fullstendige data for alle relevante variabler.

\section{Variabler}

Tidsbruk: Basert på registrert tidspunkt for ambulansens ankomst og avreise er det beregnet tidsbruk i minutter. For en fjerdedel av overdosetilfellene $(\mathrm{n}=693)$ mangler det gyldige data på tidsbruk, i de aller fleste tilfellene skyldes dette at det bare var registrert ett av tidspunktene (ankomsttid eller avreisetid), og i to tilfeller var avreisetidspunktet noe tidligere enn ankomsttidspunktet. Denne variabelen er både behandlet som kontinuerlig variabel, og gruppert i tre; $0-10$ minutter, 11-20 minutter og mer enn 20 minutter.

Ferdigbehandlet på stedet: Ambulansepersonalet krysset av for om behandlingen ble avsluttet på stedet (og eventuelt ble overført til Oslo kommunes Oppsøkende og Koordinerende Tjenester) eller transportert til legevakt eller innlagt i sykehus. Ytterligere en kategori på skjemaet var at pasienten nektet behandling, og dette var kun krysset av for ved ett overdosetilfelle. Vi har her skilt mellom de tilfellene hvor pasienten fikk en medisinsk oppfølging (transportert til legevakt eller innlagt i sykehus) og de tilfellene hvor den medisinske behandlingen ble avsluttet på stedet. Den gruppen som ikke fikk medisinsk oppfølging kalles heretter ferdigbehandlet på stedet. Det var manglende opplysninger om ferdigbehandling på stedet på 37 
av skjemaene som inngikk i vårt datasett.

Det kliniske bildet ved ambulansens ankomst ble registrert med hensyn til bevissthet og respirasjon. Begge disse var basert på ambulansepersonalets subjektive vurdering. I skjemaet var det fire kategorier for vurderingen av bevissthet: våken og klar, uklar, somnolent og komatøs. Vi har i analysene skilt mellom våkne pasienter (våken og klar eller våken og uklar), somnolente pasienter (kan holdes våkne ved stimulering) og komatøse pasienter (reagerer eventuelt kun på smertestimuli). Skjemaet hadde fire kategorier for vurdering av respirasjon: normal, hyperventilasjon, nedsatt respirasjon og respirasjonsstans. I analysene har vi skilt mellom normal respirasjon (og i noen få tilfelle hyperventilasjon), nedsatt respirasjon og respirasjonsstans. Det var manglende opplysninger om bevissthet og respirasjon for henholdsvis 37 og 112 av overdosetilfellene.

I analysene inngår også data på pasientenes kjønn og alder. Aldersvariabelen ble gruppert $\mathrm{i}$ tre for å skille ut yngre (<25 år) og eldre (40 år og eldre) fra de øvrige (26-39 år).

\section{Statistiske analyser}

Utfallsmålene (tidsbruk og ferdigbehandling på stedet) og forklaringsvariablene (pasientens kjønn og alder, og det kliniske bildet ved ankomst) er presentert i krysstabeller, med prosentandeler og oddsratioverdier. Sammenhengene er analysert med kjikvadrattester, konfidensintervall og logistiske regresjonsmodeller. Ofte er det en viss innbyrdes sammenheng mellom slike forklaringsvariable, og utfallsmålene ble derfor også analysert i en multivariat
TABELL 2: Pasienter som ble ferdigbehandlet på stedet etter overdose; etter pasientens kjønn, alder, respirasjon og bevissthet ved ankomst, og observasjonstid.

Teststatistikk

n $(\%)$

Kjikvadrat (p-verdier)

Kjønn

Menn

$1759(83)$

$1,69(0,193)$

Kvinner

$432(80)$

Alder

$<25$

$323(78)$

$6,68(0,035)$

$26-39$

1430 (83)

$40+$

437 (82)

\section{Respirasjon}

Normal

366 (79)

$8,18(0,017)$

Insuffisient

1344 (84)

Stans

397 (81)

\section{Bevissthet}

Våken

\section{Behandlingstid}

$\begin{array}{ll}0-10 \mathrm{~min} & 374(84) \\ 11-20 \mathrm{~min} & 892(85) \\ 21+\min & 317(74)\end{array}$


logistisk regresjonsanalyse. Modellen ble spesifisert ved at mulige forklaringsvariabler - basert på bivariate sammenhenger - ble trinnvis inkludert etter modelltilpasningskriterier (log likelihood ratio). På denne måten er det kun forklaringsvariabler som sammen bidrar til best mulig til å forklare variansen i utfallsmålet, som inngår i modellen.

\section{RESULTATER}

I overdosetilfellene hvor naloxone ble administrert, var pasienten oftest komatøs $(78,2$ prosent) eller somnolent $(15,6$ prosent), og respirasjonen var oftest nedsatt (62,6 prosent) eller opphørt (19,2 prosent). Gjennomsnittlig tidsbruk var 16,8 minutter (standardavvik $11,8)$, og for vel halvparten (55 prosent) av overdosetilfellene var tidsbruken mellom $10 \mathrm{og}$ 20 minutter. Tidsbruken var kortere (0-10 minutter) for 23 prosent av pasientene og lengre (> 20 minutter) for 22 prosent av pasientene. Andelen med en tidsbruk lengre enn ti minutter var høyest blant dem i aldersgruppen 40 år og eldre, blant pasienter med respirasjonssvikt (insuffisient respirasjon eller full stans) og blant komatøse pasienter (tabell 1). Også den multivariate analysen av sannsynligheten for at tidsbruken oversteg ti minutter viste at aldersgruppe og respirasjon ved ankomst var statistisk signifikante forklaringsvariabler, og sammenhengene ble lite endret i denne analysen.

Det store flertallet av overdosetilfellene (i alt 82 prosent) ble ferdigbehandlet på stedet, mens 17 prosent fikk medisinsk oppfølging (13 prosent ble transportert til legevakt og 4 prosent ble innlagt i sykehus). Andelen som ble ferdigbehandlet på stedet, var noe lavere i den yngste aldersgruppen (78 prosent). Det var ingen vesentlige forskjeller i andelen som ble ferdig behandlet på stedet med hensyn til bevissthetsnivå. Det var en noe høyere handling, og en etterfølgende observasjonstid og klargjøring for avreise. I observasjonstiden skal ambulansepersonellet vurdere pasientens tilstand og behov. Våre data inneholdt ikke noe direkte mål av obser-

\section{Denne studien viste at tidsbruken for naloxonebehandlede overdosepasienter i gjennomsnitt var på 16,8 minutter.}

andel som ble ferdigbehandlet på stedet blant dem med insuffisient respirasjon (84 prosent). Blant pasienter hvor tidsbruken oversteg 20 minutter, var det en klart lavere andel (74 prosent) som ble ferdigbehandlet på stedet, sammenliknet med pasienter med kortere tidsbruk (tabell 2).

\section{DISKUSJON}

Denne studien viste at tidsbruken for naloxonebehandlete overdosepasienter i gjennomsnitt var på 16,8 minutter. I de fleste overdosetilfellene hvor naloxone ble administrert, var pasienten komatøs, og respirasjonen var oftest nedsatt eller opphørt (19 prosent). Et stort flertall av overdosene ble ferdigbehandlet på stedet.

Få studier har tidligere beskrevet samlet behandlingstid ved prehospital behandling av opiatoverdoser, men en studie av narkotikarelaterte utrykninger i Hellas fant at gjennomsnittlig tidsbruk på stedet var i samme størrelsesorden som våre funn (26). Den samlete tidsbruken ved prehospital overdosebehandling har to komponenter; den tiden det tar fra ambulansens ankomst til stedet og til pasienten har tilfredsstillende respirasjon og bevissthet etter intravenøs naloxonebe- vasjonstiden. Men en tidligere studie hvor man brukte tilsvarende behandlingsprosedyre som i Oslo, viste at tiden fra ambulansens ankomst til pasienten hadde tilfredsstillende respirasjon og bevissthet etter intravenøs naloxonebehandling var i gjennomsnitt 9,3 minutter (31). Dette kan peke i retning av at for det store flertallet av overdosepasienter i vår studie var observasjonstiden til vurdering av pasientens tilstand og behov mindre enn ti minutter. Naloxone har kortere virketid enn heroin (32), og erfaringsmessig inntrer eller øker heroinpåvirkningen gradvis igjen etter 20-30 minutter.

På bakgrunn av anbefalt observasjonstid på minimum én time (29) kan funnene i vår studie tyde på at ambulansepersonellet i mange tilfeller ikke har hatt tilstrekkelig observasjonstid til å forsvarlig å vurdere nødvendigheten av videre medisinsk oppfølging av pasienten.

I årene 1998-2000 ble vel 80 prosent av prehospitalt naloxonebehandlete heroinoverdoser i Oslo ferdigbehandlet på stedet. Sammenliknet med funn fra andre studier er denne andelen høy, men en tilsvarende høy andel av prehospitalt behandlete overdosepasienter som ikke fikk videre medisinsk oppføl- 
ging er også funnet i tidligere studier (22-24). Det kliniske bildet av pasienten ved ambulansens ankomst, for eksempel om pasientens respirasjon hadde opphørt eller om pasienten var komatøs, var ikke av betydning for om pasienten ble ferdigbehandlet på stedet eller fikk videre medisinsk oppfølging. At livstruende kliniske tilstander med åpenbar risiko for helseskade ikke påvirker sannsynligheten for hospitalisering, sammenliknet med mindre alvorlige tilstander, er uventet. Dette kan bety at sannsynligheten for hospitalisering i større grad påvirkes av ytre omstendig- ambulansepersonellets motivasjon for å vurdere nødvendigheten av hospitalisering. Og kanskje signaliserer en forventet avvisning fra pasienten.

Studien viser at svekkelse eller stans i respirasjon ved ambulansens ankomst var vanlig blant naloxonebehandlete. Oksygenmangel, ofte av ukjent varighet, kan føre til at pasientens tilstand er preget av smerter, forvirring og kognitiv svikt når pasienten avviser videre oppfølging. Naloxone har kun effekt på opioider (33), og det kan derfor tenkes at påvirkning av andre medikamenter eller rusmidler, som benzodiazepi-

\section{Svekkelse eller stans i respirasjon ved ambulansens ankomst var vanlig blant naloxonebehandlete.}

heter enn av pasientens kliniske tilstand ved ambulansetjenestens ankomst.

I flere studier har man vist at overdosepasienter etter oppvåkning ofte motsetter seg hospitalisering eller annen medisinsk oppfølging (18). Vanlige reaksjoner etter en overdose behandlet med naloxone er abstinenssymptomer, fysiske og psykiske smerter, forvirring, stress, skam, krise- eller kaosopplevelse. Dette kan føre til hastverk med hensyn til anskaffelse av penger, heroin eller medikamenter - og til å distansere seg og fortrenge hele situasjonen.

Man må anta at tidsbruk på - og kvalitet i - ambulansepersonellets kommunikasjon og forhandling med pasienten har betydning for om pasienten hospitaliseres. Det kan tenkes at omfattende erfaring med pasienter som motsetter seg videre oppfølging, svekker ner og alkohol, vil influere på pasientens beslutning. Usikkerhet om pasientens evne til selv å vurdere behovet for hjelp tilsier derfor at transport til medisinsk klinikk for observasjon, undersøkelser og oppfølging kan være hensiktsmessig.

Avvisning av tilbud om transport til legevakt må også knyttes opp mot manglende forventninger til hva hjelpen innebærer. Å bli liggende på et observasjonsrom for medisinske undersøkelser, uten forventninger om lindrende medikamentell behandling eller annen hjelp, kan virke meningsløst. Om pasienten er uten positive forventninger om hva en hospitalisering kan innebære, kan dette synes å komme i veien for pasientens akutte behov for å komme seg ut av en uønsket overdosesituasjon med intens oppmerksomhet mot sin person, særlig når overdosen skjer i det offentlige rom.
Metodologiske betraktninger

Studien omfatter et sjeldent stort utvalg av pasienter som har vært prehospitalt behandlet for heroinoverdoser, og det er dermed god teststyrke for analysene. Det er ikke grunn til å anta at det er en systematisk utvalgsskjevhet for de overdosetilfellene som er analysert for perioden 1998-2000 i Oslo. Men, det er trolig at kjennetegn ved overdosetilfeller vil variere mellom land og at de også i Oslo har endret seg over tid i takt med nedgangen i omfanget av heroinbrukere og omfanget av ikke-fatale overdoser. Ambulansetjenestens prosedyrer i prehospital behandling av overdoser finnes i Medisinsk Operativ Manual og er siden 1998-2000 ikke endret i vesentlig grad, men økt erfaringsgrunnlag antas å ha ført til mindre justeringer av praksis. Vi antar at overførbarhet av funnene i denne studien i første rekke er med hensyn til sammenhenger, og at overførbarhet til forekomst eller nivå er mer usikker. En begrensning ved studien er at data er innsamlet for kliniske formål, ikke i forskningsøyemed. Dette innebærer antakelig mindre nøyaktighet på grunn av noe mer tilfeldige og usikre observasjoner, større internt bortfall (tidsbruksvariabelen), og mindre detaljerte opplysninger, for eksempel med hensyn til fordeling av tidsbruk på behandling og påfølgende observasjon av pasienten.

\section{Implikasjoner}

Hensynet til frivillighet hos overdosepasienten på den ene siden og forpliktelsene til å gi forsvarlig helsehjelp på den andre siden gir åpenbare utfordringer. Denne pasientgruppen har imidlertid et omfattende behandlings- og omsorgsbehov 
og oppfølging av pasienter som motsetter seg hospitalisering, bør skje som en umiddelbar forlengelse av den akuttmedisinske behandlingen. Det kan synes som om dette potensialet i liten grad har blitt utnyttet, og dette bør derfor undersøkes og vurderes.

Behandling med naloxone forer til at mange med livstruende heroinoverdoser overlever, men behandlingspraksisen kan også bidra til uforsvarlig kort observasjonstid og lav andel hospitaliseringer. Naloxone benyttet for å oppnå full bevissthet hos pasienten, gjør hospitalisering mindre sannsynlig (27). Hvordan naloxone blir administrert, med hensyn til både dosering og omfang bør derfor undersøkes.

Årsakene til at ikke alvorligheten ved overdosepasienters kliniske tilstand ved ambulansetjenestens ankomst verken påvirker behandlingstiden eller andelen pasienter som hospitaliseres bør undersøkes nærmere. Ved å anta at kommunikasjonen mellom ambulansepersonell og overdosepasient kan ha avgjørende betydning for andelen pasienter som hospitaliseres bør forbedringspotensialet undersøkes.

En studie viste at en av fire overdosepasienter søkte behandling for sine rusproblemer innen 30 dager etter overdosen (34). For dem som søkte behandling var informasjon om mulighetene avgjørende, og særlig når informasjon ble formidlet av sykehuspersonale (34). Man kan anta at tilrettelegging har betydning for både andelen pasienter som tar imot hospitalisering for medisinske undersøkelser, og for andelen som dermed kan få annen nødvendig hjelp. Et tilrettelagt mottak når det gjelder utforming, funksjon og fleksible muligheter bør derfor vurderes.

En heroinoverdose er ikke bare en kritisk medisinsk tilstand, men også uttrykk for at pasienten er i en kritisk fase av livet. Faren for påfølgende overdoser er et tydelig uttrykk for dette. Overdosepasienten evner på grunn av sin rusmiddelavhengighet i liten grad å nyttiggjøre seg mulighetene til medisinsk,
6. O'Brien P, Todd J. Hypoxic Brain Injury Following Heroin Overdose. Australian Academic Press 2009:10:169-79 7. Gråwe RW, Ruud T. Rus og psykiske lidelser i psykisk helsevern for voksne. Rapport STF78 A06003, Sintef Helse 2006

8. Landheim AS, Bakken K, Vaglum P. Gender differences in the prevalence of symptom disorders and personality disorders among poly-substance abusers and pure alcoholics. European Addiction Research 2003:9:8-17.

9. Tobin KE, Davey MA, Latkin CA. Calling emergency medical services during drug overdose: an examination of indi-

\section{Behandling med naloxone forer til at mange med livstruende heroinoverdoser}

\section{overlever.}

psykisk og sosial hjelp ut over det akutte. De bør derfor ha umiddelbar oppfølging for å gjøre behandling av lidelser og hjelp til øvrige behov oppnåelig. På bakgrunn av alvoret som en overdose representerer kan pasienten være lettere å motivere til endring enn ellers. Dermed kan faglig omsorg, kommunikasjon og formidling av håp være viktig for både å motivere til å ta imot hjelp og starte endringsprosesser.

\section{REFERANSER}

1. Darke S, Williamsom A, Ross J, Mills KL, Havard A, Teesson M. Patterns of nonfatal heroin overdose over a 3-year period: Findings for the treatment outcome study. Journal of Urban Health 2007;84:283-291.

2. Brugal MT, Barrio $B$, De La Fuente $L$, Regidor E, Royuela L, Suelves JP. Factors associated with non-fatal heroin overdose: assessing the effect of frequency and route of heroin administration. Addiction 2002;97:319-327

3. Andersen SN, Skullerud K. Hypoxic/ ischaemic brain damage, especially pallidal lesions in heroin addicts. Forensic Science International 1999;102: 51-9.

4. Brvar M, Ambrozic J, Osredkar J, Mozina M, Bunc M. S100B protein in heroin overdose: a pilot study. Critical Care 2005;9:290.

5. Darke S, Sims J, McDonalds S, Wickes W. Cognitive impairment among methadone maintenance patients. Addiction 2000;95:687-69.5 vidual, social and setting correlates. Addiction 2005;100: 397-404.

10. Håkansson A, Schlyter F, Berglund

M. Factors associated with history of non-fatal overdose among opioid users in the Swedish criminal justice system. Drug and Alcohol Dependende 2008;94:48-55.

11. Brådvik L, Frank A, Hulenvik P, Medvedeo $A$, Berglund $M$. Heroin Addicts Reporting Previous Heroin Overdoses Also Report Suicide Attempts. Suicide and Life-Threatening Behavior 2007;37:475-81

12. Rossow I. Rusmiddelbruk og suicidal atferd. Suicidologi 2001;6:5-7.

13. Neale J. Suicidal intent in nonfatal illicit drug overdose. Addiction 2000;95(1): 85-93.

14. Rossow I, Lauritzen G. Balancing on the edge of death: suicide attempts and life-threatening overdoses among drug addicts. Addiction 1999;94:209-19.

15. Coffin P, Tracy M, Bucciarelli A, Ompad D, Vlahov D, Galea S. Identifying injection drug users at risk of nonfatal overdose. Academic Emergency Medicine 2007;14:616-23.

16. Fatovich DM, Bartu A, Davis G, Atrie J, Daly FFS. Morbidity associated with heroin overdose presentations to an emergency department: A 10-year record linkage study. Emergency Medicine Australasia 2010;22:240-5.

17. Gjersing L, Biong S, Ravndal E, Waal $\mathrm{H}$, Bramnes J, Clausen T. Dødelige overdoser i Oslo 2006 til 2008: En helhetlig gjennomgang. Senter for rus-og avhengighetsforskning (SERAF); Rapport 2/201:51-2

18. Heyerdahl F, Hovda K, Bjørnås MA, Nore AK, Figueiredo JCP, Ekeberg, et al. Pre-hospital treatment of acute poisoning in Oslo. BMC Emergency Medi- 
cine 2008:8:15

19. Vilke GM, Sloane C, Smith AM Chan TC. Assessment for deaths in out-of-hospital heroin overdose patients treated with naloxone who refuse transport. Academic Emergency Medicine 2003,10:893-6.

20. Sporer KA, Firestone J, Isaacs SM Out-of-hospital treatment of opioid overdoses in an urban setting. Academic Emergency Medicine 1996;3:660-7. 21. Seidler D, Schmeiser-Rieder A, Schlarp 0, Laggner AN. Heroin and opiate emergencies in Vienna: analysis at the municipal ambulance service. Journal of Clinical Epidemiology 2000:53:734-41.

22. Dietze $P$, Cvetkovski S, Rumbold G, Miller P. Ambulance attendance at heroin overdose in Melbourne: the establishment of a database of Ambulance Service rekords. Drug and Alcohol Review 2000;19:27-33.

23. Ishøy T, Høgskilde SÅ, Haastrup L. Præhospital behandling af opioidoverdosering i København 1995-1998. Ugeskrift for Læger 2003:36:24-7.

24. Buajordet I, Næss AC, Jacobsen D, Brørs 0. Adverse events after naloxone treatment of episodes of suspected acute opioid overdose. European Journal of Emergency Medicine 2004:11:1923.

25. Boyd JJ, Kuisma MJ, Alaspää AO, Vuori E, Repo JV, Randell TT. Recurrent opioid toxicity after pre-hospital care of presumed heroin overdose patients. Acta Anaesthesiologica Scandinavica 2006:50:1266-70

26. Togia A, Sergentanis TN, Sindos M, Ntourakis D, Doumouchtsis E, Sergentanis IN, et al. Drug abuse-related emergency calls: A metropolis-wide study. Prehospital and Disaster Medicine 2008;23:36-40.

27. Dietze P, Jolley D, Cvetkovski S, Cantwell K, Jacobs I, Indig D. Characteristics of non-fatal opioid overdose attended by ambulance services in Australia. Journal of Public Health 2004:28:569-75.

28. Clarke SFJ, Dargan PI, Jones AL. Naloxone in opioid poisoning: walking the tightrope. Emergency Medicine Journal 2005;22:612-6.

29. Christenson J, Etherington J, Grafstein $E$, Innes $G$, Pennington $S$, Wanger $\mathrm{K}$, et al. Early discharge of patients with presumed opioid overdose: development of a clinical prediction rule. Academic Emergency Medicine 2000;7:1110-8. 30. Ødegård E, Rossow I. (2004): Alcohol and Non-Fatal Drug Overdoses. European Addiction Research 2004;10:168 72.

31. Wanger K, Brough L, Macmillan I, Goulding J, MacPhail I, Christenson JM. Intravenous vs subcutaneous naloxone for out-of-hospital management of presumed opioid overdose. Academic Emergency Medicine 1998;5:293-9.

32. Berkowitz BA. The relationship of pharmacokinetics to pharmacological activity: morphine, methadone and naloxone. Clinical Pharmacokinetics 1976:1:219-230.

33. Cantwell K, Dietze P, Flander L. The relationship between naloxone dose and key patient variables in the treatment og non-fatal heroin overdose in the prehospital setting. Resuscitation 2004:65:315-9.

34. Pollini RA, McCall L, Mehta SH, Vlahov D, Strathdee SA. Non-fatal overdose and subsequent drug treatment among injection drug users. Drug and Alcohol Dependence 2005; 832:104-10. 